\title{
PENGARUH MODEL PEMBELAJARAN KOOPERATIF TSTS-NHT DAN GAYA BELAJAR TERHADAP HASIL BELAJAR PENGANTAR BISNIS
}

\author{
Mendarissan Aritonang, Abdul hamid K., Julaga Situmorang \\ Universitas Methodist Indonesia, Sumatera Utara \\ tonang_4@yahoo.com
}

\begin{abstract}
Abstrak: Penelitian ini bertujuan :(1) Untuk mengetahui hasil belajar pengantar bisnis mahasiswa yang diajar dengan model pembelajaran kooperatif tipe TST lebih tinggi dari mahasiswa yang diajar dengan model pembelajaran kooperatif tipe NHT. (2) Untuk mengetahui hasil belajar pengantar bisnis mahasiswa yang memiliki gaya belajar teoritis dan mahasiswa yang memiliki gaya belajar pragmatis. (3) Untuk mengetahui interaksi antara model pembelajaran kooperatif dengan gaya belajar terhadap hasil belajar pengantar bisnis. Penelitian ini dilaksanakan di Universitas Methodist Indonesia. Populasi berjumlah 180 orang. Pengambilan sampel dilakukan dengan cluster random sampling. Metode penelitian kuasi eksperimen dengan desain faktorial $2 x$ 2 dilanjutkan dengan statistik inferensial dengan menggunakan ANAVA dua jalur dengan taraf signifikan $\alpha=0,05$ yang dilanjutkan dengan uji Scheffe. Hasil penelitian menunjukkan: (1) hasil belajar pengantar bisnis mahasiswa yang diajarkan dengan model pembelajaran kooperatif tipe TSTS lebih tinggi dari pada hasil belajar pengantar bisnis mahasiswa yang diajarkan dengan model pembelajaran kooperatif tipe NHT; (2) hasil belajar pengantar bisnis mahasiswa yang memiliki gaya belajar teoritis lebih tinggi dari pada hasil belajar pengantar bisnis mahasiswa yang memiliki gaya belajar pragmatis; (3) terdapat interaksi antara model pembelajaran kooperatif dengan gaya belajar dalam mempengaruhi hasil belajar mahasiswa.
\end{abstract}

Kata Kunci: model pembelajaran kooperatif, TST, NHT, gaya belajar, pengantar bisnis.

Abstract: This study aims: (1) To find out the introductory learning outcomes of business students who are taught with the cooperative learning model of the TST type are higher than students who are taught with the cooperative learning model of the NHT type. (2) To find out the introductory learning outcomes of business students who have theoretical learning styles and students who have pragmatic learning styles. (3) To determine the interaction between cooperative learning models with learning styles on introductory business learning outcomes. This research was conducted at the Methodist University of Indonesia. The population is 180 people. Sampling was done by cluster random sampling. Quasi-experimental research method with $2 \times 2$ factorial design followed by inferential statistics using two-way ANAVA with a significant level $\alpha=0.05$ followed by the Scheffe test. The results showed: (1) the results of introductory business learning students who were taught with the cooperative learning model type TSTS were higher than the results of introductory business learning students who were taught with the NHT type cooperative learning model; (2) the results of introductory business learning students who have theoretical learning styles are higher than the results of introductory business learning students who have pragmatic learning styles; (3) there is an interaction between cooperative learning models and learning styles in influencing student learning outcomes.

Keywords: cooperative learning model, TST, NHT, learning style, business introduction.

\section{PENDAHULUAN}

Universitas Metodist Indonesia pada jurusan Manajemen merupakan salah satu prasyarat kelulusan mahasiswa adalah dengan menguasai mata kuliah pengantar bisnis. Pada kurikulum jurusan manajemen mata kuliah pengantar bisnis merupakan mata kuliah mahasiswa semester I dimana Mata kuliah
Pengantar Bisnis merupakan salah satu mata kuliah prasyarat yang memberikan kerangka dasar bagi mahasiswa untuk mempelajari mata kuliah-mata kuliah lanjutan dan inti (mata kuliah Manajemen Sumber Daya Manusia, Manajemen Operasi, Manajemen Pemasaran, dan Manajemen Keuangan) di Program Studi Manajemen. Mata kuliah Pengantar Bisnis 
bertujuan memberikan pemahaman kepada mahasiswa tentang bagaimana suatu organisasi bisnis berupaya mencapai tujuan organisasinya dengan melakukan analisis terhadap lingkungannya untuk memenuhi kebutuhan dan keinginan konsumen yang tidak terbatas dengan sumber-sumber yang terbatas. Sebagai sebuah sistem, kegiatan bisnis merupakan sebuah sistem operasional yang sangat terkait dengan lingkungan di sekitarnya. Namun pada kenyataannya masih banyak mahasiswa yang belum mampu memahami teori pengantar bisnis ini dengan baik.

Permasalahan ini dapat diminimalkan apabila dosen dalam mengajar menggunakan model pembelajaran yang tepat dan dapat membantu mahasiswa dalam meningkatkan mutu dan keterampilannya. Menurut Purwanto (2007) dalam belajar disekolah atau perdosenan tinggi, faktor dosen dan cara mengajarnya merupakan faktor yang sangat penting. Selanjutnya sanjaya (2006) berpendapat bahwa dosen adalah komponen yang sangat menentukan dalam implementasi suatu strategi pembelajaran. Artinya faktor seorang dosen berpengaruh dalam hal peningkatan hal belajar mahasiswa. Peranan dosen diharapkan mampu mengembangkan seluruh potensi yang ada dalam diri mahasiswa.

Pembelajaran pengantar bisnis selama ini masih sangat jauh dari yang diharapkan. Penyampaian materi selalu menggunakan kebiasaan-kebiasaan yang lama dengan didominasi metode ceramah yaitu dengan menyampaikan materi perkuliahan secara langsung (direct learning) secara bertutur baik lisan (ceramah) ataupun diskusi tanpa menguraikan lebih mendalam materi yang dipelajari. Dosen mengajar cenderung textbook oriented dan belum menekankan pada kemampuan berpikir mahasiswa secara mandiri. Sehingga sebagai akibatnya muncul kebosanan dan kejenuhan dari mahasiswa untuk belajar lebih baik. Hal tersebut terjadi karena selama ini materi yang dipelajarinya tidak menyentuh kebutuhan mereka atau dengan kata lain materi yang dipelajari tidak relevan dengan pengalaman mereka sehari-hari sehingga dianggap kurang menantang, sehingga berpengaruh pada hasil belajarnya kurang baik.

Mengatasi hal tersebut maka diperlukan suatu model pembelajaran yang baru dan hendaknya dipilih sesuai dengan metode, media dan sumber belajar lainnya yang dianggap relevan dalam menyampaikan materi dalam membimbing mahasiswa secara optimal, sehingga mahasiswa dapat memperoleh pengalaman belajar dalam menumbuh kembangkan kemampuannya. Salah satu model pembelajaran yang dapat digunakan adalah model pembelajaran kooperatif tipe Two Stay Two Stray (TSTS). Model pembelajaran ini menuntut mahasiswa bekerja sendiri dan berkelompok menemukan jawaban atas apa masalah yang di hadapinya.

Menurut Jerome Bruner (1966) mengemukakan pengetahuan yang diperoleh dengan belajar penemuan menunjukkan kebaikan yaitu (1) pengetahuan itu bertahan lama atau lama diingat, (2) hasil belajar penemuan mempunyai efek transfer yang lebih baik daripada hasil belajar lainnya, (3) secara menyeluruh meningkatkan penalaran mahasiswa dan kemampuan berpikir secara bebas.

Menurut Lie (2008:12), model pembelajaran kooperatif atau disebut juga dengan pembelajaran gotong-royong merupakan sistem pengajaran yang memberi kesempatan kepada anak didik untuk bekerja sama dengan sesama siswa dalam menyelesaikan tugas-tugas yang terstruktur. Aktivitas belajar siswa merupakan salah satu faktor penting dalam kegiatan belajar mengajar. Hal ini mengingatkan bahwa kegiatan belajar mengajar diadakan dalam rangka memberikan pengalaman-pengalaman belajar pada siswa. Jika siswa aktif dalam kegiatan tersebut kemungkinan besar akan dapat mengambil pengalaman-pengalaman belajar tersebut. Kegiatan belajar dipandang sebagai kegiatan komunikasi antara siswa dan dosen. Kegiatan komunikasi ini tidak akan tercapai apabila siswa tidak dapat aktif dalam kegiatan belajar mengajar. Dengan adanya keaktifan siswa dalam proses belajar mengajar kemungkinan besar prestasi belajar yang dicapai akan memuaskan.

Selain faktor model pembelajaran yang digunakan pendidik di kelas, karakteristik peserta didik sebagai faktor dari dalam diri peserta didik juga berpengaruh terhadap hasil belajar peserta didik. Panjaitan (2006) menyatakan salah satu implikasi yang penting dalam mengkaji keberhasilan mahasiswa dalam belajar adalah perlunya diketahui faktor-faktor apa yang dapat memberikan kontribusi terhadap hasil belajar, yaitu salah satu kondisi belajar untuk mempengaruhi keefektifan pengajaran adalah karateristik pebelajar. Salah satu 
karakteristik peserta didik yang patut menjadi pertimbangan adalah gaya belajar.

\section{Hakikat Hasil Belajar Pengantar Bisnis}

"Business is an organization that provides goods or services in order toearn provit”. Bisnis adalah suatu kegiatan usaha individu yang terorganisasi untuk menghasilkan dana menjual barang ataupun jasa agar mendapatkan keuntungan dalam pemenuhan kebutuhan masyarakat dan ada di dalam insdustri. Sejalan dengan definisi tersebut, aktifitas bisnis melalui penyediaan barang dan jasa bertujuan untuk menghasilkan profit (laba). Suatu perusahaan dikatakan menghasilkan laba apabila total penerimaan pada suatu periode (Total Revenues) lebih besar dari total biaya (Total Costs) pada periode yang sama. Laba merupakan daya tarik utama untuk melakukan kegiatan bisnis, sehingga melalui laba pelaku bisnis dapat mengembangkan skala usahanya untuk meningkatkan laba yang lebih besar (Griffin dan Ebert, 1996). Sedangkan hakekat bisnis adalah usaha untuk memenuhi kebutuhan manusia, organisasi ataupun masyarakat luas. Businessman (seorang pebisnis) akan selalu melihat adanya kebutuhan masyarakat dan kemudian mencoba untuk melayaninya secara baik sehingga masyarakat menjadi puas dan senang. Dari kepuasan masyarakat itulah si pebinisnis akan mendapatkan keuntungan dan pengembangan usahanya.

Pengantar bisnis merupakan mata kuliah yang menggambarkan dasar-dasar bisnis, perusahaan dan lingkungan, manajemen perusahaan, teknik-teknik manajemen, pengembangan dan penciutan bisnis serta pengukuran keberhasilan bisnis. Tujuan dari mata kuliah ini agar, mahasiswa dapat memahami konsep-konsep, ruang lingkup, dan operasionalisasi suatu kegiatan bisnis.

Pengantar Bisnis membahas mengenai konsep-konsep dasar bisnis, sistem perusahaan, aspek teknis ekonomis, aspek hukum, aspek lokasi, spesialisasi, kombinasi dan kerjasama antar perusahaan, manajemen umum, pemasaran, produksi, pembelanjaan/keuangan, sumber daya manusia, akuntansi, statistika dan metoda kuantitatif, komputer dan sistem informasi manajemen, risiko, perluasan, dan pengukuran keberhasilan bisnis.

\section{Hakikat Model Pembelajaran Kooperatif}

Gunter et al (1990) mendefinisikan "an instructional model is a step-by step procedure that leads to specific learning outcome. Model pembelajaran adalah langkah-langkah untuk mencapai tujuan pembelajaran. Joyce \& Weil (1980) mendefinisikan model pembelajaran sebagai kerangka konseptual yang digunakan sebagai pedoman dalam melakukan pembelajaran.

Agustian (2004) mengungkapkan hal senada dengan pendapat Gunter tentang model pembelajaran yaitu model pembelajaran adalah pola pembelajaran khusus yang direncanakan untuk mencapai tujuan belajar tertentu. Model pembelajaran dirancang untuk mengarahkan belajar, dimana pendidik berperan sebagai fasilitator, membantu peserta didik memperoleh informasi, ide, keterampilan, nilai, cara berpikir dan mengekspresikan dirinya (Joyce et al : 2009).

Dengan demikian model pembelajaran merupakan kerangka konseptual yang melukiskan prosedur yang sistematis dalam mengorganisasikan pengalaman belajar untuk mencapai tujuan belajar. Jadi model pembelajaran cenderung preskriptif, yang relatif sulit dibedakan dengan strategi pembelajaran.

Selain memperhatikan rasional teoritik, tujuan dan hasil yang ingin dicapai, model pembelajaran memiliki lima unsur dasar (Joyce \& Weil ; 1980) yaitu, (1) syntax, yaitu langkahlangkah operasional pembelajaran, (2) social system, adalah suasana dan norma yang berlaku dalam pembelajaran, (3) principles of reaction, menggambarkan bagaimana seharusnya dosen memandang, memperlakukan dan merespon siswa, (4) support system, segala sarana, bahan dan alat atau lingkungan belajar yang mendukung pembelajaran, dan (5) instructional dan nurturant effects hasil belajar yang diperoleh langsung berdasarkan tujuan yang disasar (instructional effects) dan hasil belajar di luar yang disasar (nurturant effects).

Ada beragam model pembelajaran yang dikembangkan oleh para ahli pendidikan. Joyce dan Weil (dalam Sagala:2005) membagi model pembelajaran dalam 4 kelompok yaitu: (1) kelompok model pemrosesan informasi yang memusatkan perhatian pada pengembangan kemampuan kreatif, (2) kelompok model pengajaran sosial yang menekankan pada usaha membangun sikap siswa agar memiliki kecakapan untuk berhubungan dengan orang lain sebagai usaha membangun sikap siswa yang demokratis dengan menghargai setiap perbedaan dalam realitas sosial 3) kelompok model pembelajaran personal yang menekankan 
pada pengembangan kepribadian individu siswa denga memperhatikan kehidupan emosional dan (4) kelompok model pengajaran sistem perilaku yang menekankan pada usaha untuk mengembangkan kemampuan siswa memecahkan masalah belajar melalui penguraian perilaku ke dalam jumlah yang kecil dan berurutan.

\section{Model Pembelajaran Kooperatif Tipe Two Stay Two Stray (TSTS)}

Pembelajaran kooperatif pertama kali muncul dari para filosofis di awal abad Masehi yang mengemukakan bahwa dalam belajar seseorang harus memiliki pasangan atau teman sehingga teman tersebut dapat diajak untuk memecahkan suatu masalah. Menurut Anita Lie (2004:12), model pembelajaran kooperatif atau disebut juga dengan pembelajaran gotongroyong merupakan sistem pengajaran yang memberi kesempatan kepada anak didik untuk bekerja sama dengan sesama siswa dalam menyelesaikan tugas-tugas yang terstruktur.

Model pembelajaran kooperatif (Cooperatif Learning) adalah model belajar mengajar yang didesain untuk mengembangkan kerjasama dan tanggung jawab siswa. Model ini dirancang untuk mengurangi persaingan yang banyak ditemui di kelas dan cenderung mengarah pada pola "kalah dan menang" (Slavin, 1994). Definisi di atas menjelaskan bahwa model pembelajaran kooperatif merupakan model pembelajaran yang menekankan adanya kerjasama antara siswa dalam kelompok untuk mencapai tujuan belajar.

Pengelompokkan siswa secara heterogen dimaksudkan untuk mengembangkan penerimaan siswa terhadap keragaman dan keterampilan sosial. Pada dasarnya model pembelajaran kooperatif dikembangkan untuk mencapai paling tidak 3 tujuan pembelajaran yaitu hasil belajar, penerimaan terhadap keragaman, dan pengembangan keterampilan sosial (Corebima, dkk.2002). Melalui anggota kelompoknya baik kemampuan akademik, jenis kelamin, usia, latar belakang sosial, ekonomi, dan budaya. Para siswa juga diharapkan menerima keragaman tersebut dan memaksimalkan kerja sama kelompok, sehingga masing-masing anggota kelompok siap menghadapi tes dan hasil belajar akan tercapai dengan optimal.

Selain itu ada kelebihan heterogen dalam metode belajar kooperatif yaitu memberikan kesempatan kepada siswa untuk saling mengajar (Peer Tutoring) dan meningkatkan interaksi serta memudahkan dosen dalam mengelola kelas (Lie,2002:42).

Mbulu (2001:72) menyebutkan bahwa dalam setiap pembelajaran, siswa harus merasakan bahwa aktivitas yang dilakukannya memperoleh sukses. Setiap sukses yang diperoleh merupakan reinforcement yang memacu aktivitas belajar menjadi lebih kuat untuk memperoleh sukses berikutnya. Kesuksesan suatu pembelajaran dapat dilihat dari peningkatan hasil belajar. Jadi dengan memberikan penghargaan, maka siswa akan lebih termotivasi untuk meningkatkan hasil belajarnya.

\section{Model Pembelajaran Kooperatif Tipe NHT}

Teori pendukung selanjutnya adalah teori yang dikemukakan Vygotsky, ada empat prinsip dalam teori Vygotsky yang dikutip (Ratumanan, 2004) sebagai berikut: (1) penekanan pada hakekat sosial budaya belajar adalah menekankan pentingnya peranan lingkungan sosial dan interaksi sosial dalam belajar. Interaksi sosial ini mengacu terbentuknya ide baru dan memperkaya perkembangan interlektual siswa, (2) zona perkembangan terdekat (zone of proximal development), seorang siswa berada dalam kondisi belajar konsep yang paling baik apabila konsep itu berada dalam zona perkembangan terdekat. Siswa bekerja dalam tugas-tugas yang tidak dapat mereka pecahkan sendiri, tugas tersebut dapat diselesaikan dengan teman sebaya yang lebih mampu. Pada saat siswa bekerja sama, kemungkinan sekali ada tingkat kinerja salah seorang anggota kelompok pada suatu tugas tertentu itu berada pada tingkat kognitif sedikit lebih dari tingkat kinerja siswa lain, (3) pemagangan kognitif (cognitif Apprenticeship), konsep ini mengacu pada proses seseorang yang sedang belajar secara tahap demi tahap memperoleh keahliah interaksinya dengan seseorang pakar. Pakar yang dimaksud disini adalah orang yang menguasai permasalahan yang dipelajari, jadi dapat berupa orang dewasa atau teman sebaya. Pemagangan dapat dilakukan dengan melibatkan siswa dalam tugas-tugas kelompok heterogen. Dalam kelompok tersebut siswa yang lebih pandai membantu siswa yang kurang pandai dalam menyelesaikan tugas-tugas kelompok tersebut, (4) perancah (sconffolding) pemberian pada seseorang sejumlah besar bantuan, kemudian mengurangi bantuan 
tersebut dan memberikan kesempatan kepada anak tersebut mengambil alih tanggungjawab yang semakin besaar setelah ia dapat melakukannya. Bantuan dapat berupa petunjuk, dorongan, peringatan, menguraikan maslah ke dalam langkah-langkah pemecahan, memberikan contoh, tindakan-tindakan lain yang memungkinkan siswa itu belajar mandiri.

Teori Piaget juga merupakan salah satu teori pendukung pembelajaran kooperatif. Perkembangan kognitif manusia pada dasarnya seiring dengan perubahan kemampuan mental manusia dari waktu ke waktu. Menurut Isjoni (2010) kaitan teori Piaget dalam pembelajaran kooperatif adalah memfokuskan pada proses berpikir anak tidak sekedar pada produknya, pengenalan dan pengakuan terhadap anak atas keterlibatan dalam proses pembelajaran dan penerimaan perbedaan individu dalam kemajuan perkembangan. Dalam pembelajaran kooperatif NHT sumbangan penting dari teori piaget pada langkah 1 (penomoran) dan langkah 3 (berpikir bersama). Pada langkah 1 mengelompokkan siswa ke dalam kelompokkelompok belajar dengan mempertimbangkan dengan tingkat kemampuan yang berbeda, pada langkah tiga siswa saling berinteraksi dan bekerja sama dalam mengerjakan tugas-tugas sedangkan dosen membimbing dan memberikan dorongan kepada kelompok-kelompok belajar agar dapat menemukan sendiri

Menurut Arends (2008:16) model pembelajaran kooperatif tipe NHT dilaksanakan dengan langkah-langkah sebagai berikut: (1) siswa dibagi dalam beberapa kelompok dan masing-masing siswa dalam setiap kelompoknya mendapatkan nomor urut, (2) dosen memberikan tugas dan masing-masing kelompok mengerjakan permasalahan, (3) kelompok memutuskan jawaban yang dianggap paling benar dan memastikan setiap anggota kelompok mengetahui jawaban ini, (4) dosen menyebutkan salah satu nomor dan siswa yang bernomor tersebut melaporkan hasil kerja kelompok, dan (5) jika memungkinkan, dosen dapat mengubah komposisi kelompok sehingga siswa yang memiliki nomor sama membentuk kelompok baru.

Pembelajaran kooperatif NHT menurut Kagan seperti yang dikutip (Lie, 2008) akan memberikan kesempatan kepada siswa untuk membagikan ide-ide dan mempertimbangkan jawaban yang paling tepat serta mendorong siswa untuk meningkatkan semangat kerjasama mereka. Pembelajaran kooperatif tipe NHT dapat mendorong suksesnya keaktifan siswa dalam kelompok. Setiap anggota kelompok perlu mengetahui jawaban kelompok siswa sehingga membantu teman sekelompoknya, ini berarti mereka membantu dirinya sendiri dan kelompoknya, dengan demikian siswa akan menjadi lebih aktif dalam proses pembelajaran

Pembelajaran tipe kepala bernomor yang dikembangkan Kagan (Ibrahim dkk, 2000 : 28) dalam penerapannya berfokus kepada keterlibatan lebih banyak siswa dalam menelaah materi yang tercakup dalam suatu pelajaran dan mengecek pemahaman mereka terhadap isi pelajaran tersebut. Sebagai ganti dosen mengajukan pertanyaan atau tugas kepada seluruh anggota kelas, dan dosen menggunakan sruktur empat langkah: (1) Penomoran. Dosen membagi siswa dalam kelompok atau tim yang beranggotakan 3 hingga 5 orang dan memberi mereka nomor sehingga setiap siswa dalam kelompok tersebut me-miliki nomor berbeda, (2) Pengajuan pertanyaan. Dosen mengajukan pertanyaan atau memberikan tugas dan masing-masing kelompok mengerjakannya, (3) Berpikir bersama. Setiap anggota kelompok mendiskusikan jawaban yang benar dan memastikan tiap anggota kelompok dapat mengerjakannya atau mengetahuinya, (4) Pemberian jawaban. Dosen memanggil satu nomor tertentu dan para siswa dari tiap kelompok dengan nomor yang sama mengangkat tangan dan menyampaikan jawaban untuk seluruh kelas secara bergiliran, siswa lain dengan nomor yang sama dapat memberikan tanggapan, kemudian dosen menyimpulkan.

\section{Hakikat Gaya Belajar}

De Porter dan Hernacki (2003) menyatakan bahwa "gaya belajar merupakan kombinasi dari bagaimana Anda menyerap, dan kemudian mengatur serta mengolah informasi". Drummond (dalam Ardi, 2007) mendefinisikan gaya belajar sebagai "an individual's preferred mode and desired conditions of learning."

Sedangkan Nasution mengemukakan bahwa gaya belajar adalah cara yang dilakukan seseorang dalam menangkap stimulus dan informasi, cara mengingat berpikir dan memecahkan soal. Selanjutnya juga dikatakan bahwa gaya belajar ini berhubungan dengan proses-proses kemampuan yang dimiliki seseorang. 
Gaya belajar mengacu pada cara belajar yang lebih disukai pebelajar. Umumnya, dianggap bahwa gaya belajar seseorang berasal dari variabel kepribadian, termasuk susunan kognitif dan psikologis latar belakang sosio cultural, dan pengalaman pendidikan (Nunan, 1991: 168).

Keanekaragaman gaya belajar siswa perlu diketahui pada awal permulaannya diterima pada suatu lembaga pendidikan yang akan ia jalani. Hal ini akan memudahkan bagi pebelajar untuk belajar maupun pembelajar untuk mengajar dalam proses pembelajaran. Pebelajar akan dapat belajar dengan baik dan hasil belajarnya baik, apabila ia mengerti gaya belajarnya. Hal tersebut memudahkan pembelajar dapat menerapkan pembelajaran dengan mudah dan tepat ( Kolb 1984 ).

Pada pertengahan tahun 1970 Peter Honey dan Alan Mumford (Coffiels et al 2004) mengembangkan model David Kolb untuk disesuaikan dan digunakan dalam dunia bisnis. Instrumennya dikenal dengan nama Learning Style Questionaire (LSQ). Dua adaptasi dilakukan untuk model pengalaman Kolb. Pertama tahap-tahap dalam model kolb disesuaikan dengan pengalaman manajerial pengambilan keputusan atau pemecahan masalah. Tahapan Honey dan Mumford adalah memiliki pengalaman, meninjau pengalaman, pembuatan simpulan dari pengalaman, dan perencanaan langkah-langkah selanjutnya. Kedua, gaya secara langsung disesuaikan dengan tahapan-tahapan dalam siklus dan bernama aktivis, reflekstor, teoris dan pragmatis.

\section{Gaya Belajar Teoris}

Tipe Teoris biasanya digambarkan sebagai "Pemikir", senang memikirkan secara mendalam, menganalisis tahap demi tahap dan mengevaluasi sehingga mereka bisa mendapatkan kesimpulan yang logis. Mereka senang untuk mendiskusikan fakta, teori, model, dan sistem serta mereka bisa menjadi tidak nyaman dan tidak sabar dengan sesuatu yang mereka nilai sebagai konsep atau aktifitas nyata. Mereka cenderung memiliki pendekatan metodikal, dan mereka cenderung menanyakan banyak persoalan, kadangkala menantang informasi, konsep, atau proses yang sedang dipresentasikan. Mereka menginginkan tujuan yang jelas dan objektif, menyukai berkerja secara mandiri, dan mungkin saja tidak menyadari peran dalam memainkan latihan dan simulasi.

Teoris hebat dalam asumsi dasar, prinsip, teori, model dan sistem pikir. Mereka menjunjung tinggi rasionalitas dan logika. Mereka cenderung objektif (melepaskan diri dari permasalahan ketika memikirkannya), analitis dan tidak menyukai pengalamanpengalaman subjektif dan ambigu (tidak jelas). Mereka senang mengumpulkan fakta-fakta yang terpencar menjadi teori logis yang saling berhubungan. Mereka senang untuk mengatur merapikan fakta dan menyusunnya ke dalam skema rasional.

Tabel 1. Gaya Belajar Teoris

\begin{tabular}{|c|c|}
\hline $\begin{array}{l}\text { Belajar dengan baik pada aktifitas } \\
\text { ketika: }\end{array}$ & $\begin{array}{l}\text { Mengalami hambatan belajar, dan } \\
\text { mungkin akan menentang ketika: }\end{array}$ \\
\hline $\begin{array}{l}\text { Apa yang ditawarkan kepada mereka } \\
\text { merupakan bagian dari system, model atau } \\
\text { teori. } \\
\text { Mereka tertantang secara intelektual. Cont: } \\
\text { diuji dalam sesi tutorial, memiliki } \\
\text { kesempatan untuk mempertanyakan dan } \\
\text { menyelidiki/memeriksa metodologi dasar, } \\
\text { asumsi-asumsi atau logika. } \\
\text { - Mereka berada dalam situasi yang terstruktur } \\
\text { dengan tujuan yang jelas. } \\
\text { - Mereka ditawarkan ide-ide dan konsep yang } \\
\text { menarik meskipun ide atau konsep tersebut } \\
\text { tidak begitu relevan. } \\
\text { Mereka diminta untuk memahami dan } \\
\text { berpartisipasi dalam situasi yang rumit. }\end{array}$ & 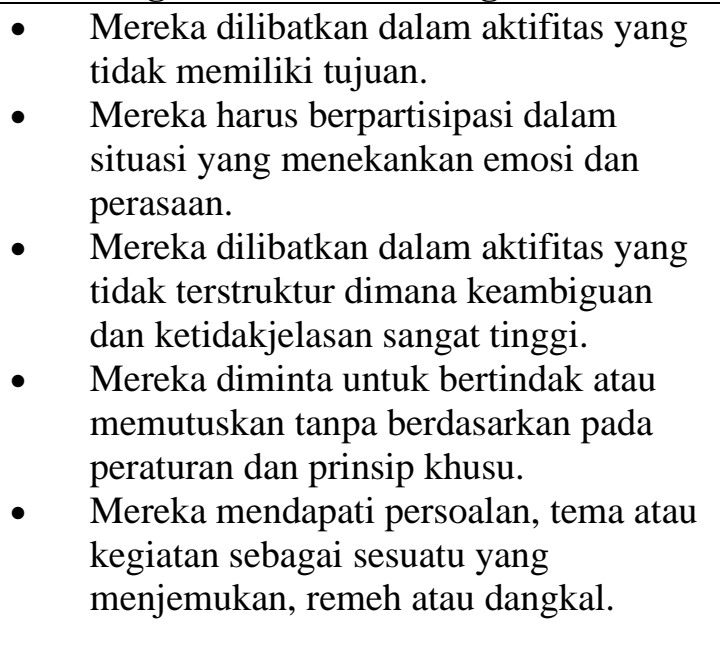 \\
\hline
\end{tabular}

\section{Gaya Belajar Pragmatis}


Tipe Pragmatis juga disebut sebagai "Perencana", yang suka memecahkan permasalahan atau persoalan. Mereka bisa menjadi tidak sabar dengan teori yang terlalu banyak dan diskusi yang terlalu lama. Mereka ingin mengetahui bagaimanakah caranya untuk bisa mengaplikasikan apa yang telah mereka pelajari di "dunia nyata", dan mereka ingin langsung mencoba kasus - terjun langsung ke situasi yang sebenarnya dan mencoba hal tersebut sendiri.

Pragmatis secara positif mencari ide baru dan langsung mengambil kesempatan

Tabel 2. Gaya Belajar Pragmatis

\begin{tabular}{|l|}
\hline Belajar dengan baik pada aktifitas ketika: \\
\hline - Mereka bisa melihat hubungan nyata antara \\
tema/aktifitas dengan pekerjaan atau \\
kehidupan mereka. \\
- Mereka diperkenalkan kepada ide-ide atau \\
teknik untuk melakukan sesuatu yang jelas- \\
jelas memiliki keuntungan praktis dan \\
memiliki kualitas tampilan (face validity) \\
yang tinggi. \\
- Mereka memiliki kesempatan untuk \\
mencoba dan mempraktekkan teknik dengan \\
bimbingan/umpan balik dari ahli yang \\
terpercaya. \\
- Mereka diberikan kesempatan untuk \\
melaksanakan apa yang telah mereka \\
pelajari. \\
Mereka bisa berkosentrasi pada masalah- \\
masalah khusus. Cont: menggambarkan \\
rencana kerja dengan sasaran atau hasil yang \\
jelas.
\end{tabular}

Mengalami hambatan belajar, dan mungkin akan menentang ketika:

- Isi, keterampilan atau pengetahuan tidak dipersepsikan berhubungan dengan kebutuhan mendesak yang mereka rasakan atau memiliki relevansi dan keuntungan praktis.

- Tidak ada praktek/latihan atau panduan yang jelas mengenai bagaimana cara untuk melakukannya.

- pengajar atau isi terlihat terlihat terpisah dari realita. Cont: di dunia entah berantah.

- Mereka merasa bahwa orang-orang hanya berputar-putar di lingkaran dan tidak keluar dengan cepat.

- Tidak ada penghargaan yang jelas-jelas bisa didapat dari belajar, atau terdapat hambatan untuk melaksanakan/ mengimplementasikan apa yang akan atau sedang dipelajari.
Masalah penelitian adalah: (1) Apakah terdapat perbedaan hasil belajar pengantar bisnis mahasiswa yang dibelajarkan dengan model pembelajaran kooperatif tipe TSTS dan yang dibelajarkan dengan model pembelajaran kooperatif tipe NHT?; (2) Apakah terdapat perbedaan hasil belajar mahasiswa yang memiliki gaya belajar teoris dan pragmatis?; dan (3) Apakah terdapat interaksi antara model pembelajaran dan gaya belajar terhadap hasil belajar pengantar bisnis mahasiswa?

\section{METODE}

Penelitian ini akan dilakukan di Fakultas Ekonomi Universitas Methodist Indonesia Medan Jurusan Manajemen. Populasi dalam penelitian ini adalah seluruh mahasiswa Jurusan Manajemen Semester I. Sampel merupakan sebahagian dari populasi yang dipilih secara representatif, artinya karakteristik populasi tercermin dalam sampel yang diambil. Adapun sampel dalam penelitian ini adalah Mahasiswa Jurusan Manajemen Semester 1 yang berjumlah 40 orang kelas A dan 40 orang kelas B. Mahasiswa diambil secara cluster random sampling. Satu kelas sebagai kelas eksperimen yang dibelajarkan dengan model pembelajaran kooperatif tipe TSTS dan kelas eksperimen yang lain dibelajarkan dengan model pembelajaran kooperatif tipe NHT.

Penelitian ini digolongkan penelitian quasi eksperimen dengan desain faktorial $2 \times 2$. Penelitian ini melibatkan 2 kelompok sampel yang ditetapkan sebagai kelompok eksperimen. Kelompok eksperimen masing-masing diberlakukan model pembelajaran kooperatif 
tipe TSTS dan model pembelajaran kooperatif digambarkan sebagai berikut:

tipe NHT. Rancangan eksperimen dapat

Tabel 3. Rancangan Eksperimen Disain Faktorial 2 x 2

\begin{tabular}{|l|l|l|}
\hline \multirow{2}{*}{ Gaya belajar $(\mathrm{B})$} & Model Pembelajaran $(\mathrm{A})$ & \\
\cline { 2 - 3 } & Model Pembelajaran TSTS $\left(\mathrm{A}_{1}\right)$ & Model pembelajaran NHT $\left(\mathrm{A}_{2}\right)$ \\
\hline Teoris $\left(\mathrm{B}_{1}\right)$ & $\mathrm{A}_{1} \mathrm{~B}_{1}$ & $\mathrm{~A}_{2} \mathrm{~B}_{1}$ \\
\hline Pragmatis $\left(\mathrm{B}_{2}\right)$ & $\mathrm{A}_{1} \mathrm{~B}_{2}$ & $\mathrm{~A}_{2} \mathrm{~B}_{2}$ \\
\hline
\end{tabular}

Keterangan :

$\mathrm{A} \quad=$ model pembelajaran

$\mathrm{B} \quad=$ gaya belajar

$\mathrm{A}_{1} \quad=$ model pembelajaran kooperatif tipe TSTS

$\mathrm{A}_{2} \quad=$ model pembelajaran kooperatif tipe

NHT

$\mathrm{B}_{1} \quad=$ gaya belajar teoris

$\mathrm{B}_{2} \quad=$ gaya belajar pragmatis

$\mathrm{A}_{1} \mathrm{~B}_{1}=$ Hasil belajar mahasiswa yang dibelajarkan dengan model pembelajaran kooperatif tipe TSTS dan memiliki gaya belajar teoris

$\mathrm{A}_{1} \mathrm{~B}_{2}=$ Hasil belajar mahasiswa yang dibelajarkan dengan model pembelajaran kooperatif tipe TSTS dan memiliki gaya belajar pragmatis

$\mathrm{A}_{2} \mathrm{~B}_{1}=$ Hasil belajar mahasiswa yang dibelajarkan dengan model pembelajaran kooperatif tipe NHT dan memiliki gaya belajar teoris

$\mathrm{A}_{2} \mathrm{~B}_{2}=$ Hasil belajar mahasiswa yang dibelajarkan dengan pembelajaran kooperatif tipe NHT dan memiliki gaya belajar pragmatis

Teknik analisa data yang digunakan adalah teknik statistik inferensial dan deskriptif. Teknik statistik deskriptif digunakan untuk mendeskripsikan data, antara lain : nilai ratarata (mean), median, modus, standar deviasi, dan kecenderungan data. Teknik statistik inferensial digunakan untuk menguji hipotesis penelitian, dimana teknik inferensial yang digunakan adalah teknik analisis varians dua jalur dengan taraf signifikan 0,05. Sebelum teknik ini digunakan perlu dilakukan uji persyaratan. Uji persyaratan yang dilakukan adalah uji normalitas menggunakan uji Lilliefors dan uji homogenitas menggunakan uji Fisher dan uji Bartlett (Sudjana, 1992). Karena terdapat interaksi antar variabel maka analisis dilanjutkan dengan uji Scheffe karena $n$ berbeda. Selanjutnya untuk keperluan pengujian hipotesis, dirumuskan hipotesis statistik penelitian sebagai berikut:

a. Hipotesis Pertama

$$
\begin{aligned}
& \mathrm{H}_{\mathrm{o}}: \mu \mathrm{A}_{1}=\mu \mathrm{A}_{2} \\
& \mathrm{H}_{\mathrm{a}}: \mu \mathrm{A}_{1}>\mu \mathrm{A}_{2}
\end{aligned}
$$

b. Hipotesis Kedua

$\mathrm{H}_{\mathrm{o}}: \mu \mathrm{B}_{1}=\mu \mathrm{B}_{2}$

$\mathrm{H}_{\mathrm{a}}: \mu \mathrm{B}_{1}>\mu \mathrm{B}_{2}$

c. Hipotesis Ketiga

$\mathrm{H}_{\mathrm{o}}: \mathrm{A}><\mathrm{B}=0$

$\mathrm{H}_{\mathrm{a}}: \mathrm{A}><\mathrm{B} \neq 0$

Keterangan :

A $=$ model pembelajaran

$\mathrm{B} \quad=$ gaya belajar

$\mathrm{A}_{1} \quad=$ model pembelajaran kooperatif tipe TSTS

$\mathrm{A}_{2} \quad=$ model pembelajaran kooperatif tipe NHT

$\mathrm{B}_{1} \quad$ =gaya belajar teoris

$\mathrm{B}_{2} \quad$ =gaya belajar pragmatis

$\mu \mathrm{A}_{1} \quad=$ Rata-rata hasil belajar yang diperoleh dengan model pembelajaran kooperatif tipe TSTS

$\mu \mathrm{A}_{2} \quad$ =Rata-rata hasil belajar yang diperoleh dengan model pembelajaran kooperatif tipe NHT

$\mu \mathrm{B}_{1} \quad=$ Rata-rata hasil belajar mahasiswa yang memiliki gaya belajar teoris

$\mu B_{2} \quad=$ Rata-rata hasil belajar mahasiswa yang memiliki gaya belajar pragmatis.

\section{HASIL DAN PEMBAHASAN \\ Hasil}

Berdasarkan data skor tes hasil belajar pengantar bisnis mahasiswa, langkah berikutnya adalah menghitung total skor dan rata-rata skor tiap kelompok perlakuan menurut tabel ANAVA, yang selanjutnya dapat digunakan sebagai dasar keputusan statistik untuk pengujian hipotesis, seperti pada Tabel 4 sebagai berikut: 
Tabel 4. Ringkasan Hasil Statistik Deskriptif Data Perhitungan

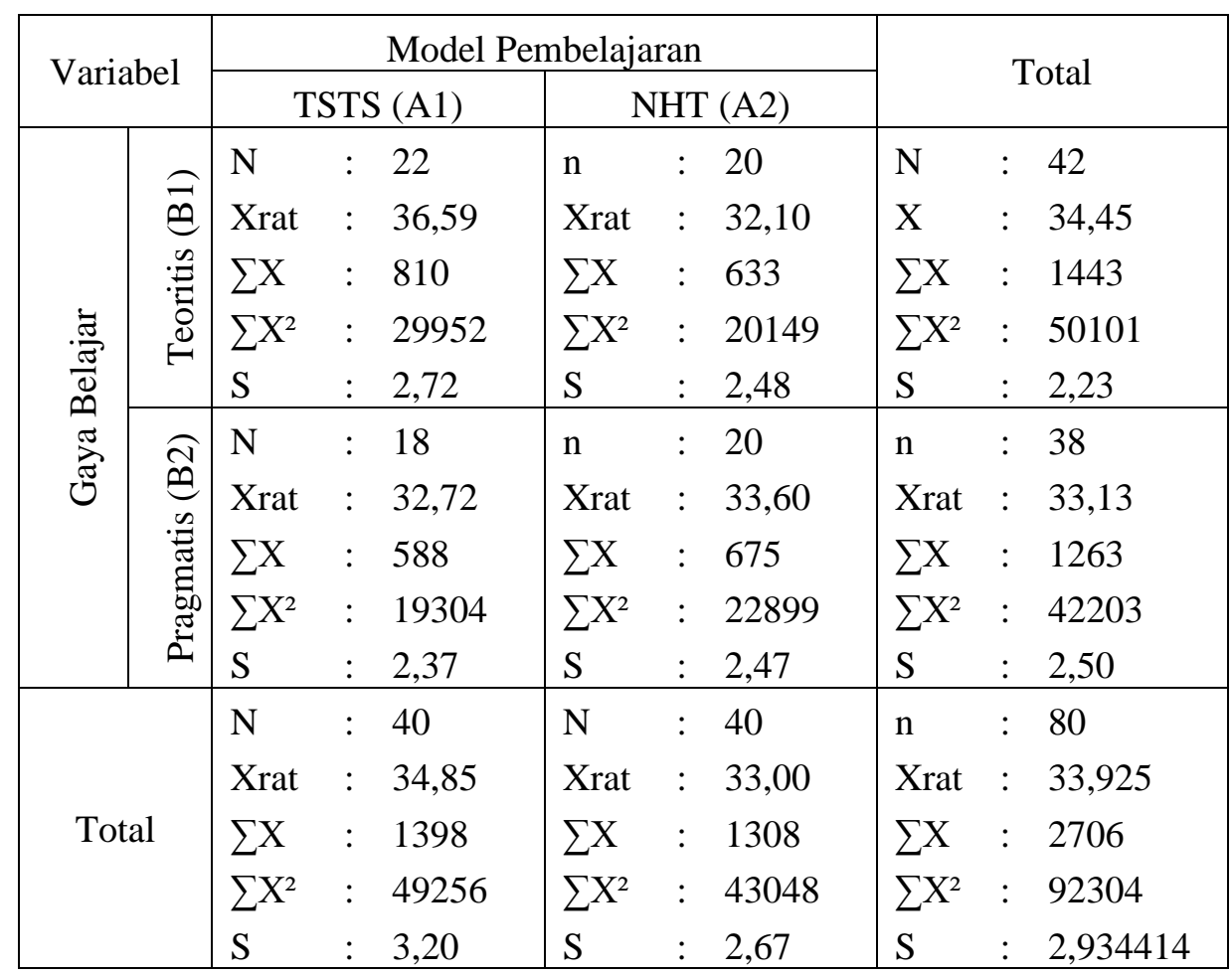

Tabel 5 . Rangkuman Hasil Anava Secara Keseluruhan Terhadap Hasil belajar Pengantar Bisnis

\begin{tabular}{|l|c|c|c|c|c|}
\hline \multicolumn{1}{|c|}{ Sumber variasi } & $\mathrm{dk}$ & $\mathrm{JK}$ & $\mathrm{RJK}$ & $\mathrm{F}_{\text {hitung }}$ & $\begin{array}{c}\mathrm{F}_{\text {tabel(1.63) }} \\
(\alpha=0.05)\end{array}$ \\
\hline Model Pembelajaran (A) & 1 & 25,038 & 25,038 & 4,158 & \\
Gaya Belajar (B) & 1 & 101,25 & 101,25 & 16,817 & 3,96 \\
Interaksi (A x B ) & 1 & 189,688 & 189,688 & 31,506 & \\
Galat & 76 & 457,572 & 6,020 & & \\
\hline Total & $\mathbf{7 9}$ & & & & \\
\hline
\end{tabular}

Perbedaan Hasil belajar Pengantar Bisnis Antara MahasiswaYang Diajar dengan Model Pembelajaran Kooperatif Tipe TSTS dan Model Pembelajaran Kooperatif Tipe NHT

Adapun hipotesis statistik yang diuji adalah

Ho : $\mu \mathrm{A} 1=\mu \mathrm{A} 2$

$\mathrm{Ha}: \mu \mathrm{A} 1>\mu \mathrm{A} 2$

Dari hasil analisis data diperoleh ratarata nilai model pembelajaran kooperatif tipe TSTS adalah 34,85 dan rata-rata nilai model pembelajaran kooperatif tipe NHT adalah 33,00. Berdasarkan hasil pengujian hipotesis pada tabel 24 di atas, maka diperoleh hasil perhitungan data model pembelajaran, dimana $\mathrm{F}_{\text {hitung }}=4,158$ sementara nilai kritik $\mathrm{F}_{\text {tabel }}$ dengan $\mathrm{dk}=(1,76)$ dan $\alpha=0,05$ adalah sebesar
3,96 Hasil ini menunjukkan bahwa $\mathrm{F}_{\text {hitung }}=$ 4,158> $\mathrm{F}_{\text {tabel }}=3,99$ sehingga Hipotesis Nol (Ho) ditolak dan (Ha) diterima, dengan demikian hipotesis penelitian yang menyatakan bahwa hasil belajar pengantar bisnis mahasiswa yang dibelajarkan dengan model pembelajaran kooperatif tipe TSTS lebih tinggi dari pada mahasiswayang diajarkan dengan model pembelajaran kooperatif tipe NHT teruji kebenarannya.

\section{Perbedaan Hasil belajar Pengantar Bisnis Antara MahasiswaYang Memiliki Gaya belajar teoritis dan Gaya belajar pragmatis}

Adapun hipotesis statistik yang diuji adalah :

Ho $: \mu \mathrm{B} 1=\mu \mathrm{B} 2$

Ha $: \mu \mathrm{B} 1>\mu \mathrm{B} 2$

Dari hasil analisis data diperoleh rata-rata nilai gaya belajar teoritis adalah 34,85 dan 
rata-rata nilai tipe gaya belajar pragmatis adalah 33,13. Berdasarkan hasil pengujian hipotesis pada tabel 24 di atas diperoleh hasil perhitungan data gaya belajar, dimana $\mathrm{F}_{\text {hitung }}=$ 16,817 dan nilai kritik $F_{\text {tabel }}$ dengan $\mathrm{dk}=(1,75)$ dan $\alpha=0,05$ adalah 3,96. Hasil ini menunjukkan bahwa $\mathrm{F}_{\text {hitung }}=16,817>\mathrm{F}_{\text {tabel. }}=$ 3,96 sehingga Hipotesis Nol (Ho) ditolak, dengan demikian hipotesis penelitian yang menyatakan bahwa mahasiswa yang memiliki gaya belajar teoritis memperoleh hasil belajar Pengantar Bisnis yang lebih tinggi dari pada mahasiswa yang memiliki gaya belajar pragmatis teruji kebenarannya.

Interaksi Antara Model Pembelajara dan Gaya Belajar Mahasiswa Terhadap Hasil belajar Pengantar Bisnis

Adapun hipotesis statistik yang diuji adalah :

Ho: $\mathrm{A}><\mathrm{B}=0$

$\mathrm{Ha}: \mathrm{A}><\mathrm{B} \neq 0$

Dari hasil analisis data rata-rata nilai model pembelajaran kooperatif tipe TSTS yang memiliki gaya belajar teoritis adalah 36,59 . Rata-rata nilai Model pembelajaran kooperatif tipe TSTS yang memiliki gaya belajar pragmatis adalah 32,72 . Rata-rata nilai model pembelaran NHT yang memiliki gaya belajar teoritis adalah 32,10. Rata-rata nilai Model Pembelajaran Kooperatif Tipe NHT yang memiliki gaya belajar pragmatis adalah 33,60

Berdasarkan hasil pengujian hipotesis di atas diperoleh perhitungan interaksi model pembelajaran dengan gaya belajar mahasiswa, dimana $F_{\text {hitung }}=31,506$ dan nilai kritik $F_{\text {tabel }}$ dengan $\mathrm{dk}=(1,76)$ dan $\alpha=0.05 \%$ adalah 3,96 . Hasil ini menunjukkan bahwa $F_{\text {hitung }}=31,506>$ $F_{\text {tabel. }}=3,99$ sehingga Hipotesis Nol (Ho) ditolak, dengan demikian hipotesis penelitian yang menyatakan bahwa terdapat interaksi antara model pembelajaran dan gaya belajar mahasiswa dalam memberikan pengaruh terhadap hasil belajar Pengantar Bisnis teruji kebenarannya.

Karena ada interaksi antara model pembelajaran dan gaya belajar dalam mempengaruhi hasil belajar Pengantar Bisnis, maka perlu dilakukan uji lanjutan (post hoc test), untuk mengetahui rata-rata hasil belajar sampel mana yang berbeda. Untuk melihat bentuk interaksi antara model pembelajaran dan gaya belajar dalam mempengaruhi hasil belajar Pengantar Bisnis, dilakukan uji lanjut dengan menggunakan uji Scheffe.

Tabel 6. Ringkasan Hasil Perhitungan Uji Scheffe

\begin{tabular}{|c|c|c|c|}
\hline $\begin{array}{c}\text { Skor kelompok } \\
\text { yang dibandingkan }\end{array}$ & $\mathrm{F}_{\text {hitung }}$ & $\mathrm{F}_{\text {tabel }(376)}$ & \multirow{2}{*}{ Ket. } \\
\cline { 2 - 3 } & & $\alpha=0,05$ & \\
\hline$\mu \mathrm{A} 1 \mathrm{~B} 1$ dengan $\mu \mathrm{A} 2 \mathrm{~B} 1$ & 5,923 & 2.75 & Signifikan \\
\hline$\mu \mathrm{A} 1 \mathrm{~B} 1$ dengan $\mu \mathrm{A} 2 \mathrm{~B} 2$ & 3,940 & 2.75 & Signifikan \\
\hline$\mu \mathrm{A} 1 \mathrm{~B} 1$ dengan $\mu \mathrm{A} 1 \mathrm{~B} 2$ & 4,960 & 2.75 & Signifikan \\
\hline$\mu \mathrm{A} 2 \mathrm{~B} 1$ dengan $\mu \mathrm{A} 2 \mathrm{~B} 2$ & 2,733 & 2.75 & Signifikan \\
\hline$\mu \mathrm{A} 2 \mathrm{~B} 2$ dengan $\mu \mathrm{A} 1 \mathrm{~B} 2$ & 0,780 & 2.75 & Tidak Signifikan \\
\hline$\mu \mathrm{A} 1 \mathrm{~B} 2$ dengan $\mu \mathrm{A} 2 \mathrm{~B} 1$ & 1,101 & 2.75 & Tidak Signifikan \\
\hline
\end{tabular}

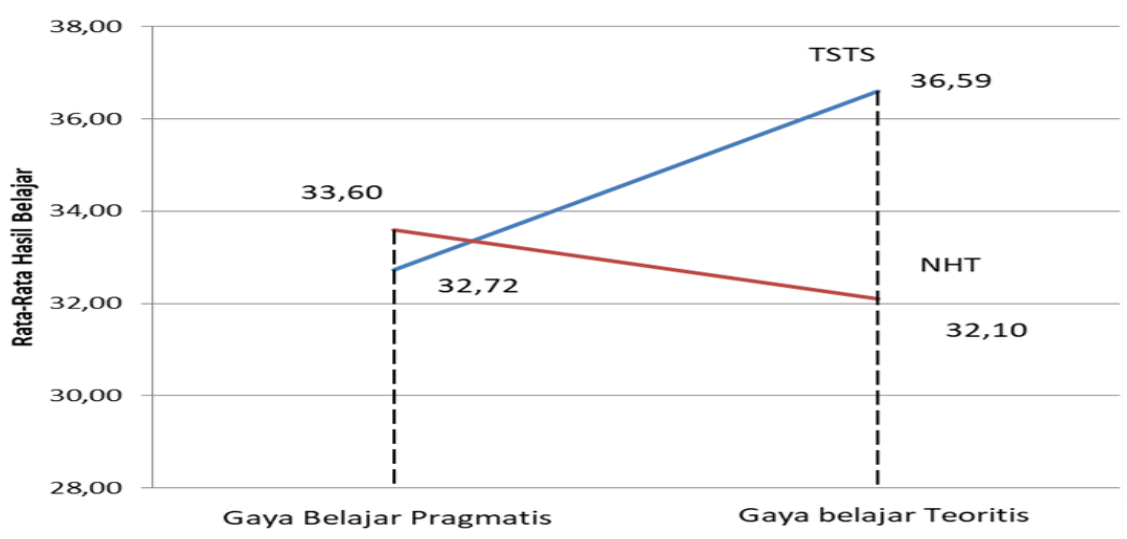

Gambar 1. Model Interaksi Antara Model Pembelajaran dan Gaya Belajar Terhadap Hasil belajar Pengantar Bisnis Mahasiswa 


\section{Pembahasan}

Hasil Belajar Pengantar Bisnis Mahasiswayang Dibelajarkan dengan Model Pembelajaran Kooperatif Tipe TSTS Lebih Tinggi Dibandingkan yang Dibelajarkan dengan Model Kooperatif Tipe NHT

Berdasarkan komponen dan langkahlangkah penerapan masing-masing model, bahwa perbedaannya adalah terletak pada adanya diskusi antar kelompok di tipe TSTS dan adanya penomoran di tipe NHT. Pada tipe TSTS, Mahasiswaberdiskusi di dalam kelompoknya sendiri dan berkesempatan berdiskusi lagi dengan sebagian anggota kelompok lain. Selanjutnya membagi informasi di kelompok asal. Kesempatan untuk berdiskusi dengan kelompok lain memberi peluang kepada mahasiswa untuk lebih banyak menggali informasi, lebih banyak ide yang bisa didapat dan dibagi, lebih banyak tugas yang bisa dilakukan, lebih banyak kesempatan berinteraksi dengan anggota kelompok yang berbeda. Sedangkan pada tipe NHT mahasiswa hanya berdiskusi sesama kelompok untuk menyelesaikan permasalahan yang ada. Tidak ada interaksi secara langsung dengan kelompok lain dalam menyelesaikan permasalahan, selain di akhir sesi ketika dosen meminta jawaban dengan memanggil nomor dan dipresentasikan oleh nomor yang dipanggil.

Jika membandingkan kedua model pembelajaran maka diketahui bahwa pada model pembelajaran kooperatif selain mahasiswa berlatih menyelesaikan masalah sendiri dan menemukan pengetahuan sendiri, mahasiswa juga dilatih untuk bekerjasama dalam kelompok, sehingga pembelajaran yang diperoleh Mahasiswajuga lebih bermakna. Selain itu, belajar secara kooperatif juga memungkinkan mahasiswa mengeksplor pengetahuan lebih luas, tidak monoton tergantung pada satu sumber dan materi yang ada saja.

Berdasarkan uraian yang telah dikemukakan di atas, dapat disimpulkan bahwa hasil belajar mahasiswa yang diajar dengan model pembelajaran kooperatif tipe TSTS lebih tinggi dibandingkan dengan mahasiswa yang diajar dengan model pembelajaran kooperatif tipe NHT.

Hasil Belajar Pengantar Bisnis Mahasiswayang Memiliki Gaya Belajar Teoris Lebih Tinggi Dibandingkan yang Memiliki Gaya Belajar Pragmatis
Membandingkan kedua tipe gaya belajar diperoleh bahwa tipe teoris cenderung tertantang secara intelektual, suka dengan ide dan konsep-konsep tidak terlalu suka dengan yang praktis dan tidak mendalam. Sedangkan tipe pragmatis tidak terlalu fokus pada teori akan tetapi lebih fokus pada melakukan apa yang telah dipelajari dan suka berkonsentrasi pada masalah-masalah khusus.

Selanjutnya tipe teoris tidak mampu belajar jika tidak mengetahui tujuannya belajar, tidak suka persoalan dangkal dan remeh, yang tidak jelas dan ambigu, sedangkan tipe pragmatis mungkin akan kesulitan jika belajar tanpa praktek, aktivitas monoton, dan tidak ada penghargaan yang jelas.

Jika ditinjau dari segi mata kuliah pengantar bisnis, maka mata kuliah ini cenderung bersifat teori dan tidak terlalu banyak praktek-praktek kerja di lapangan. Mata kuliah ini juga cenderung mata kuliah yang berisi teori-teori, konsep-konsep, pendapat ahli yang memerlukan pemikiran dan analisa yang mendalam untuk benar-benar memahami materinya. Mata kuliah pengantar bisnis ini mungkin lebih menarik menurut tipe Teoris dibandingkan tipe Pragmatis. Tipe Teoris dengan mudah memahami mata kuliah ini karena mata kuliah ini memberi tantangan kepada tipe teoris untuk menganalisis dan memahami teori secara mendalam. Sebaliknya bagi tipe Pragmatis mata kuliah ini mungkin terasa membosankan karena dipenuhi teori-teori tanpa praktek, tidak menuntut aplikasi langsung ke lapangan. Sehingga tipe teoris lebih mudah menguasai mata kuliah ini dibandingkan tipe pragmatis. Oleh karena itu dapat disimpulkan bahwa terdapat perbedaan hasil belajar pengantar bisnis mahasiswayang memiliki gaya belajar teoris dan pragmatis.

Interaksi antara Model Pembelajaran dan Gaya Belajar Terhadap Hasil Belajar Pengantar Bisnis

Selanjutnya, pada tipe NHT ciri khasnya adalah tiap anggota kelompok diberi nomor untuk kemudian bersiap-siap nomornya dipanggil dan menjawab pertanyaan yang diajukan. Hal ini bisa menjadi kelebihan juga kelemahan dari tipe ini. Kelebihannya adalah karena tiap anggota tidak tahu nomor berapa yang akan dipanggil, maka setiap anggota pasti akan bersiap-siap untuk dipanggil dan berusaha untuk mengetahui jawaban dari hasil diskusi. Kelemahannya adalah siswa hanya terfokus 
untuk menjawab pertanyaan, diskusi berjalan hanya sekedar untuk menjawab pertanyaan. Diskusi menjadi tidak berkembang, dan karena jawaban harus diketahui oleh seluruh anggota, akhirnya akan ada anggota yang hanya berharap jawaban dari anggota lain, tanpa berusaha mencari dan tidak antusias berdiskusi

Dalam model pembelajaran tipe NHT ini hal yang dilakukan dosen adalah dengan melemparkan pertanyaan dengan anggota kelompok yang dibentuk, dan setiap anggota kelompok akan saling membantu demi tanggung jawab dan nama baik kelompok masing-masing. Dengan pembelajaran ini diharapkan mahasiswa antusias dalam memahami permasalahan dan tanggung jawabnya karena merasa merekalah yang ditunjuk dosen untuk menjawab.

Adapun kelemahan model pembelajaran tipe NHT ini kemungkinan nomor yang dipanggil, dipanggil lagi oleh dosen, tidak semua anggota kelompok dipanggil oleh dosen, siswa yang pandai akan cenderung mendominasi sehingga dapat menimbulkan sikap minder dan pasif dari siswa yang lemah, proses diskusi tidak dapat berjalan lancar jika ada siswa yang sekedar menyalin pekerjaan siswa yang pandai tanpa memiliki pemahaman yang memadai.

Jika dikaitkan dengan gaya belajar tipe teoris cenderung tidak terlalu cocok dengan model NHT karena tidak mangakomodasi kebutuhan berpikir tipe ini. Tipe ini suka belajar dengan tujuan yang jelas, yang mengakomodsi kebutuhan berpikir, mengeluarkan ide-ide dan membahas teori secara mendalam. Dalam pembelajaran NHT mahasiswa seolah hanya dituntut untuk menguasai teori saja, dan hanya berusaha menguasai permasalahan yang akan ditanyakan dosen. Tipe teoris merasa tidak cukup puas karena belajar hanya untuk menghafal materi yang disampaikan guru saja. Sedangkan untuk tipe pragmatis, tipe ini cenderung lebih merasa aman jika dibelajarkan dengan model kooperatif tipe NHT, karena tipe ini cenderung cepat bosan jika belajar hanya melulu teori dan terlalu banyak berdiskusi seperti pada tipe TSTS, sedangkan pada tipe NHT tipe pragmatis hanya perlu menghafal teori dan bersiap-siap untuk menjawab pertanyaan yang mungkin akan ditanyakan oleh dosen kepadanya. Sehingga dapat diketahui bahwa mahasiswa tipe teoris memperoleh hasil belajar yang lebih tinggi jika dibelajarkan dengan tipe TSTS dan mahasiswa tipe pragmatis memperoleh hasil belajar yang lebih tinggi jika dibelajarkan dengan tipe NHT. Sehingga dapat disimpulkan terdapat interaksi antara model pembelajaran kooperatif dan gaya belajar dalam mempengaruhi hasil belajar mahasiswa.

\section{PENUTUP}

1. Model pembelajaran kooperatif tipe TSTS dan tipe NHT berpengaruh signifikan terhadap hasil belajar Pengantar Bisnismaha mahasiswa dimana hasil belajar Pengantar Bisnis maha mahasiswa yang dibelajarkan dengan model pembelajaran kooperatif tipe TSTS lebih tinggi dibandingkan maha mahasiswa yang dibelajarkan dengan model pembelajaran kooperatif tipe NHT.

2. Gaya belajar berpengaruh signifikan terhadap hasil belajar Pengantar Bisnismaha mahasiswa dimana hasil belajar mahasiswayang memiliki gaya belajar Teoris lebih tinggi dibandingkan maha mahasiswa yang memiliki gaya belajar Pragmatis.

3. Terdapat interaksi antara model pembelajaran kooperatif dan gaya belajar dalam mempengaruhi hasil belajar Pengantar Bisnis. Maha mahasiswa dengan gaya belajar Teoris akan memperoleh hasil belajar yang lebih tinggi jika dibelajarkan dengan model pembelajaran kooperatif tipe TSTS. Sebaliknya mahasiswa yang memiliki gaya belajar Pragmatis akan memperoleh hasil belajar yang lebih tinggi jika dibelajarkan dengan model pembelajaran kooperatif tipe NHT.

\section{DAFTAR PUSTAKA}

Agustian, Ary, Ginanjar. (2004). ESQ Power Sebuah Inner Journey Melalui al-Ihsan, Jakarta: Arga.

Arends, Richard I. (2008). Learning To Teach. Jakarta. Pustaka Belajar

Bruner, J. S. (1966). Toward a Theory of Instruction. Harvad University. Cambridge.

Coffied, F, et al. (2004). Learning Style and Pedagogy in post-16 Learning A Syatematic and Critical Review. London: Cromwell Press Ltd.

Corebima, dkk.(2002). Teori Konstruktivisme. Jakarta: Direktorat SLTP Ditjen Dikdasmen Depdiknas. 
DePorter, Bobbi dan Hernacki, Mike. (2013). Quantum Learning: Membiasakan Belajar nyaman dan Menyenangkan. Bandung: Kaifa Learning.

Griffin, Ricky W dan Ebert, Ronald J. (2008). Bisnis ,ed 8 jilid 1. Jakarta: Erlangga

Ibrahim, M. Dkk. (2000). Pembelajaran Kooperatif. Surabaya Pusat Sains dan Matematika Sekolah Program Pascasarjana Unesa. Universitas Press.

Isjoni. (2011). Cooperative Learning Efektifitas Pembelajaran Kelompok. Bandung: Alfabeta.

Joyce Bruce and Weil Marsha, (1980). Models Of Teaching. New Delhi. Prentice Hall.

Joyce, Bruce. (2009). Models of Teaching: Advance Organizer. New Jersey: Pearson education Inc. 247-261.

Kolb, D, A. (1984) Experiential Learning Experience as The Source of Learning and Development. New Jersey: Prentice Hall.

Lie, Anita. (2008). Cooperative Learning. Jakarta. Grasindo
Mbulu, J.(2001). Pengajaran Individual. Malang: Yayasan Elang Mas.

Nasution, S. (2006). Kurikulum dan Pengajaran. Jakarta: Bumi Aksara.

Nunan, David.(1991). Language Teaching Methodology; A Textbook for Teachers New York: Prentice Hall \& Co.

Panjaitan, B. (2006). Karateristik Pebelajar Dan Konstirbusinya Terhadap Hasil Belajar. Medan : Penerbit Poda.

Purwanto. (2004). Psikologi Pendidikan. Bandung: PT. Remaja Rosdakarya.

Ratumanan, T. G. (2002). Belajar dan Pembelajaran. Surabaya: Unesa.

Sagala, (2003). Konsep dan Makna Belajar Mengajar. Bandung: Alfabeta.

Sanjaya, Wina. (2008). Strategi Pembelajaran. Jakarta. Kencana

Slavin, Robert E. (1995). Cooperative Learning: Teory, Research and Praktice (2 ed). Boston: Allyn and Bacon Piblicher

Sudjana. (2002). Metode Statistika, Bandung: Tarsito. 